2019-10-22

\title{
A global atlas of the environmental risk of marinas on water quality
}

Valdor, P

http://hdl.handle.net/10026.1/15900

10.1016/j.marpolbul.2019.110661

Marine Pollution Bulletin

Elsevier

All content in PEARL is protected by copyright law. Author manuscripts are made available in accordance with publisher policies. Please cite only the published version using the details provided on the item record or document. In the absence of an open licence (e.g. Creative Commons), permissions for further reuse of content should be sought from the publisher or author. 


\title{
A global atlas of the environmental risk of marinas on water quality
}

\author{
Paloma F. Valdor ${ }^{\mathrm{a}}$, Aina G. Gómez ${ }^{\mathrm{a}, *}$, José A. Juanes ${ }^{\mathrm{a}}$, Camille Kerléguer ${ }^{\mathrm{a}}$, Peter Steinberg, ${ }^{\mathrm{b}, \mathrm{c}}$, \\ Edwina Tanner ${ }^{\mathrm{b}}$, Catriona MacLeod ${ }^{\mathrm{d}}$, Antony M. Knights ${ }^{\mathrm{e}}$, Rochelle D. Seitz ${ }^{\mathrm{f}}$, Laura Airoldi ${ }^{\mathrm{g}}$, \\ Louise B. Firth ${ }^{\mathrm{e}}$, Tasman Crowe ${ }^{\mathrm{h}}$, Eva Chatzinikolaou ${ }^{\mathrm{i}}$, Alison Smith ${ }^{\mathrm{f}}$, Christos Arvanitidis ${ }^{\mathrm{i}}$, \\ John A. Burt ${ }^{\mathrm{j}}$, Paul R. Brooks ${ }^{\mathrm{h}}$, Massimo Ponti ${ }^{\mathrm{g}}$, Abilio Soares-Gomes ${ }^{\mathrm{k}}$, Aida Ovejero, \\ Gonzalo Méndez ${ }^{1}$
}

${ }^{a}$ Environmental Hydraulics Institute, Universidad de Cantabria - Avda. Isabel Torres, 15, Parque Científico y Tecnológico de Cantabria, 39011, Santander, Spain

${ }^{\mathrm{b}}$ Sydney Institute of Marine Science, 19 Chowder Bay Rd, Mosman, NSW, 2088, Australia

${ }^{\mathrm{c}}$ School of BEES, University of New South Wales Sydney, NSW, 20152, Australia

${ }^{\mathrm{d}}$ Institute for Marine and Antarctic Studies (IMAS), University of Tasmania, Australia

${ }^{\mathrm{e}}$ School of Biological and Marine Sciences, Plymouth University, Plymouth, UK

${ }^{\mathrm{f}}$ Virginia Institute of Marine Science, William \& Mary, Virginia, USA

${ }^{g}$ Department of Biological, Geological and Environmental Sciences and Interdepartmental Research Centre for Environmental Sciences, UO CoNISMa, University of

Bologna, Via S. Alberto 163, 48123, Ravenna, Italy

${ }^{\mathrm{h}}$ UCD Earth Institute and School of Biology and Environmental Science, University College Dublin, Dublin, Ireland

${ }^{\mathrm{i}}$ Institute of Marine Biology, Biotechnology and Aquaculture Hellenic Centre for Marine Research, Attiki, Greece

${ }^{\mathrm{j}}$ Center for Genomics and Systems Biology, New York University Abu Dhabi, Abu Dhabi, United Arab Emirates

${ }^{\mathrm{k}}$ Sediment Ecology Laboratory, Marine Biology Department, Federal Fluminense University, Rio de Janeiro, Brazil

${ }^{1}$ UNESCO Chair in Sustainable Coastal Zone Management, University of Vigo, Vigo, Spain

\section{A R T I C L E I N F O}

\section{Keywords:}

Recreational boating

Marinas

Environmental management

Global scale

\begin{abstract}
A B S T R A C T :
Estimating the potential environmental risks of worldwide coastal recreational navigation on water quality is an important step towards designing a sustainable global market. This study proposes the creation of a global atlas of the environmental risk of marinas on water quality by applying the Marina Environmental Risk Assessment (MERA) procedure. Calculations integrate three main risk factors: Pressure, State and Response. Applying the MERA approach to 105 globally distributed marinas has confirmed the utility, versatility and adaptability of this procedure as a novel tool to compare the environmental risks within and among regions (i.e. for area-based management), to identify the world's best practices (i.e. to optimize existing management) and to understand and adjust global risks in future development (i.e. improved planning).
\end{abstract}

\section{Introduction}

The world and its coastlines are becoming increasingly urbanised. Today, nearly $40 \%$ of the global population lives within $100 \mathrm{~km}$ of the coast (Firth et al., 2016), but by 2035 this is estimated to increase to between 50 and 75\% (Haslett, 2009; United Nations, 2015a, 2018). In fact, 13 of the 20 most populous cities in the world are coastal with large commercial and recreational ports (United Nations, 2015a). Indeed, of the 71 cities with over 5 million inhabitants, 62\% (44) are located on the coast (McGranahan et al., 2007; Seto et al., 2011). There is no sign of slow-down in urbanisation of coastal areas (Haslett, 2009; Seto et al., 2011; Widmer and Underwood, 2004). One consequence of increased urbanization of the world's coastlines is greater anthropogenic pressure and risks to the environment (Pearson et al., 2016), from expanding commercial and recreational use of coastal waterways. This includes tourism, which is one of the fastest growing economic sectors in the world (ECORYS, 2015; UNWTO, 2017).

Expansion of the maritime tourism industry contributes with cruise

\footnotetext{
${ }^{*}$ Corresponding author.

E-mail addresses: palomavaldor@gmail.com (P.F. Valdor), aina.gomez@unican.es (A.G. Gómez), juanesj@unican.es (J.A. Juanes), kerle.camille@gmail.com (C. Kerléguer), p.steinberg@unsw.edu.au (P. Steinberg), Edwina.Tanner@sims.org.au (E. Tanner), catriona.macleod@utas.edu.au (C. MacLeod), antony.knights@plymouth.ac.uk (A.M. Knights), seitz@vims.edu (R.D. Seitz), laura.airoldi@unibo.it (L. Airoldi), louise.firth@plymouth.ac.uk (L.B. Firth), tasman.crowe@ucd.ie (T. Crowe), evachatz@hcmr.gr (E. Chatzinikolaou), asmith@vims.edu (A. Smith), arvanitidis@hcmr.gr (C. Arvanitidis), john.burt@nyu.edu (J.A. Burt), paul.brooks@ucd.ie (P.R. Brooks), massimo.ponti@unibo.it (M. Ponti), abiliosg@id.uff.br (A. Soares-Gomes), aovejero@uvigo.es (A. Ovejero), mendez@uvigo.es (G. Méndez).
} 
ships and ecotourism operating side-by-side in many of our coastal cities (Brida and Zapata, 2009; Kovačić, 2016). The populations of coastal cities are also becoming more affluent, leading to increases in recreational boating and boat-ownership (Davenport and Davenport, 2006; Gómez et al., 2017). Globally, marinas are the main infrastructure that support these boating activities and are important local, regional and national drivers of socio-economic progress. While marinas provide substantial economic competitiveness and financial success (Kovačić, 2016), boating activities (and associated infrastructure) can have the potential to impact and possibly degrade the environment (Moreau, 2009) and its associated ecosystem services (Carić et al., 2016) as: seabed alterations (PIANC, 2006); invasive species introduction (Dafforn et al., 2009; Knights et al., 2016; Rivero et al., 2013); changes on water and sediment quality (EPA, 1985; Mali et al., 2017; Neira et al., 2017, 2018; Turner, 2010; Warnken et al., 2004); or habitat loss (Lenders et al., 2001; Ryu et al., 2011; Smith and Shackley, 2006; Whitfield and Becker, 2014). The increasing numbers of marinas is recognised as a significant environmental stressor in many regions (e.g., EPA, 2003; Di Franco et al., 2011; Y1lmaz et al., 2014; Gómez et al., 2017).

Given the predicted increase in recreational and touristic boating in coastal ecosystems and potential for environmental damage (Bishop et al., 2015), discussion on the long-term sustainability of this important sector should be included in any policy debate related to globalization and environmental sustainability (United Nations, 2015b). Sustainable Development Goal (SDG) 14 in the UN 2030 Sustainable Development Agenda requires us to "conserve and sustainably use the oceans, seas and marine resources for sustainable development" (United Nations, 2015b), by means of continuous progress on concepts, establishment of goals, creation of indicators, and definition of values on which common strategies can be based (Kates et al., 2005; Knights et al., 2016; Mihalic, 2016). Environmental management should be based on the continuous improvement framework by introducing adaptive, flexible, and dynamic methods (ISO, 2015). International networks can facilitate the development of adaptive methods through information exchange and generating common effective solution to collective problems (as the Port International Navigation Association, PIANC, www.pianc.org, or the World Harbour Project, WHP, www. worldharbourproject.org, Steinberg et al., 2016).

Larger ports routinely have access to, and can employ, a range of environmental management tools. However, these management strategies are rare in smaller ports or marinas (Knights et al., 2016; Pearson et al., 2016; Parra et al., 2018), and as such management practices can be sub-optimal (Kuznetsov et al., 2015). There is a need for an elementary approach to collecting information about the nature and extent of impacts from the boating sector and to estimate both the independent and cumulative risk to coastal waters of these operations (Goodsir et al., 2015). Collation of this information would provide managers with the necessary data to make informed decisions regarding sustainable development in their systems at a range of scales. Recently, Gómez et al. (2019) outlined an approach, which mapped the environmental risks of marinas on water quality. Their Marina Environmental Risk Assessment (hereafter MERA) reviewed the general characteristics of marinas (including hydromorphological characteristics, human pressures, environmental conditions, and environmental management), and combined these data with readily accessible information on specific marina locations to generate an environmental risk ranking. The procedure, based on the Pressure-State-Response model (OECD, 2003), was used to assess 320 marinas along the Spanish coast and provide a map of the environmental risks of marinas on water quality at the Iberian Peninsula scale. The atlas allowed data to be viewed spatially; regional impacts and multiple marinas can therefore be visualised, providing a better understanding of potential cumulative environmental impacts following human activities in marinas. Indeed, the authors argue that this knowledge is a pre-requisite for a more targeted area-based management of aquatic systems quality across a range of scales. Implementing the MERA approach at a global level provides a means to characterise and compare marinas, allowing (i) the scale of risks (local vs. global) from marinas to be assessed, and (ii) providing opportunities to develop scale-appropriate management strategies and to identify commonalities, which can increase management measure success (Knights et al., 2013).

This work takes advantage of the WHP network to undertake a global MERA review. WHP partners contributed data on 105 marinas located on five continents worldwide to: 1) confirm the adequacy of the conceptual model, indicators and assessment system identified by Gomez et al. (2019); 2) provide a global assessment of marina conditions; and 3) assure an optimal management strategy at either local, national or global scales.

\section{Materials and methods}

\subsection{Marina environmental risk assessment (MERA)}

The MERA calculations integrates three main factors: Pressure, State and Response (Gómez et al., 2019) (Equation (1)):

$\mathrm{R}_{\mathrm{i}}=\mathrm{Pr}_{\mathrm{i}} \mathrm{XSt}_{\mathrm{i}}+\mathrm{Rs}_{\mathrm{i}}$

Where $R_{i}$ is a term that describes the environmental risk of marinas on water quality, $\operatorname{Pr}_{i}$ captures the combined environmental Pressures, $\mathrm{St}_{\mathrm{i}}$ provides a measure of the current environmental State (environmental conditions) and $\mathrm{Rs}_{\mathrm{i}}$ is the Response to mitigate, adapt to or prevent human-induced negative impacts on the water quality of a (i) marina.

Pressure ("Pr" in Equation (1) above) is estimated by considering four parameters as the main driving forces: intensity of navigation $\left(\mathrm{NV}_{\mathrm{i}}\right)$, marina operation activities $\left(\mathrm{MA}_{\mathrm{i}}\right)$, probability of requirement of dredging interventions $\left(\mathrm{DG}_{\mathrm{i}}\right)$ and external activities $\left(\mathrm{EX}_{\mathrm{i}}\right)$ (Equation (2)).

$\mathrm{Pr}_{\mathrm{i}}=\mathrm{NV}_{\mathrm{i}}+\mathrm{MA}_{\mathrm{i}}+\mathrm{DG}_{\mathrm{i}}+\mathrm{EX}_{\mathrm{i}}$

Intensity of navigation $\left(\mathrm{NV}_{\mathrm{i}}\right)$ is estimated as the density of boats housed by a marina (boats $/ \mathrm{m}^{2}$ ). This is calculated by dividing the number of berths by the water surface where marina activity takes place. Marina operation activities $\left(\mathrm{MA}_{\mathrm{i}}\right)$ are assessed by considering presence (1) or absence (0) of main fuel stations and dry docks within the marina boundaries. The structural type of marinas (1: interior; 0.5 : dock; 0: anchorage) and the type of substrate when the marina is a harbour (1: mud; 0.7: sand; 0.3: gravel; 0: rocky) are used as surrogates to assess the need for dredging $\left(\mathrm{DG}_{\mathrm{i}}\right)$. Finally, activities at the periphery of the marinas $\left(\mathrm{EX}_{\mathrm{i}}\right)$ are valued by identifying primary land uses within a $1 \mathrm{~km}$ buffer distance around the marina (1.0: industrial, mining, urban; 0.5: agricultural; 0: natural or semi-natural). The highest category value will be adopted (worst case scenario) when assessing the external activity at a marina level.

State ("St" in Equation (1) above) is estimated by considering three parameters which directly related to the environmental conditions: susceptibility $\left(\mathrm{SU}_{\mathrm{i}}\right)$, ecological value $\left(\mathrm{EV}_{\mathrm{i}}\right)$ and naturalness $\left(\mathrm{NA}_{\mathrm{i}}\right)$ (Equation (3)).

$\mathrm{St}_{\mathrm{i}}=\mathrm{SU}_{\mathrm{i}}+\mathrm{EV}_{\mathrm{i}}+\mathrm{NA}_{\mathrm{i}}$

Susceptibility $\left(\mathrm{SU}_{\mathrm{i}}\right)$ is estimated by calculating the flushing capacity using the Complexity Tidal Range Index (CTRI) method (Gómez et al., 2017). Ecological value $\left(\mathrm{EV}_{\mathrm{i}}\right)$ is assessed by computing the number of protected areas within a $1 \mathrm{~km}$ buffer distance around the area where the marina activity takes place. Finally, naturalness $\left(\mathrm{NA}_{\mathrm{i}}\right)$ is valued by considering the potential alteration by hydromorphological pressures using the marina's structural type (dock: 0 ; interior or harbour: 0.5 ; anchorage: 1).

Response ("Rs" in Equation (1) above) is estimated considering two parameters linked to the likely response: adopted environmental measures $\left(\mathrm{AM}_{\mathrm{i}}\right)$ and adopted environmental instruments $\left(\mathrm{AI}_{\mathrm{i}}\right)$ (Equation 
(4)).

$\mathrm{Rs}_{\mathrm{i}}=\mathrm{AM}_{\mathrm{i}}+\mathrm{AI}_{\mathrm{i}}$

Adopted measures $\left(\mathrm{AM}_{\mathrm{i}}\right)$ are estimated by considering the number of adopted environmental measures undertaken by the marina, such as garbage disposal, waste management, bilge management, and oil management. Adopted instruments parameter $\left(\mathrm{AI}_{\mathrm{i}}\right)$ is assessed by computing the number of adopted environmental management procedures relevant to the marina, including Blue Flag (FEE, 2007), ISO14001:2015 (International Organization for Standardization; ISO, 2015), EMAS (Eco-Management and Audit Scheme; European Commission, 2009), Blue Star Marina (International Marine Certification Institute; Manigel, 2011), among others.

Once all parameters are calculated, results are normalized by reference to the maximum values across all marinas and discarding outliers for each parameter with values greater than $\overline{\mathrm{x}} \pm 3$ SSD (Gómez et al., 2019).

Finally, risk factors are categorised into four categories with values between 1 and 4 (for Pressure and State factors) or into two categories with values of either 0 or 4 (for Response factor). The percentile system (P25, P50, P75) of the observed values is used to define the criteria among the different categories to favour a dynamic management and continuous improvement (Gomez et al., 2019) (Table 1). Marinas are classified at: very high-risk $\left(R_{i} \geq 15\right)$, high-risk $\left(10 \leq R_{i}<15\right)$, moderate-risk $\left(5 \leq R_{i}<10\right)$, low-risk $\left(1<R_{i}<5\right)$, and very low-risk $\left(R_{i}=1\right)$.

\subsection{Data collection}

Marinas under study are classified into four structural types: i) harbour, an artificial shelter constructed for ships normally protected by two breakwaters; ii) dock, an area artificially enclosed by docks; iii) anchorage, a natural shelter for ships by anchoring, mooring to buoys, or exceptionally, by berthing; and, iv) interior, a natural or artificial shelter invading land areas with sea water, normally with a breakwater (Gómez et al., 2017). Marinas are also classified using one of the three water categories based on predominant salinity regime, namely: coastal, freshwater and estuarine waters. A general tree of relative percentages of occurrence of structural types and water categories is then developed understanding how the marinas are distributed across the area under study (see Fig. 2).

A standardised questionnaire is used to gather information from marina managers and to estimate MERA (Fig. 1).

In addition to consulting with marina managers a range of other resources such as local public databases (e.g. governance websites, and websites associated with regional tourism and environmental groups) is also consulted. Where possible, data collected is cross-checked using global (e.g. skipper.adac.de) and local resources or is specifically sourced from each marina (e.g. the official web page of each marina).

Table 1

Thresholds levels used to identify Pressure, State and Response categories used for MERA.

\begin{tabular}{llll}
\hline Factor & Category & Criteria* $^{*}$ & Global thresholds \\
\hline \multirow{2}{*}{ Pressure } & $\mathrm{VL} \mathrm{(1)}$ & $\mathrm{Pr}_{\mathrm{i}} \leq \mathrm{P} 25$ & $\mathrm{Pr}_{\mathrm{i}} \leq 1.5$ \\
& $\mathrm{~L}(2)$ & $\mathrm{P} 25<\mathrm{Pr}_{\mathrm{i}} \leq \mathrm{P} 50$ & $1.5<\mathrm{Pr}_{\mathrm{i}} \leq 2.2$ \\
& $\mathrm{M}(3)$ & $\mathrm{P} 50<\mathrm{Pr}_{\mathrm{i}} \leq \mathrm{P} 75$ & $2.2<\mathrm{Pr}_{\mathrm{i}} \leq 2.7$ \\
State & $\mathrm{H} \mathrm{(4)}$ & $\mathrm{Pr}_{\mathrm{i}}>\mathrm{P} 75$ & $\mathrm{Pr}_{\mathrm{i}}>2.7$ \\
& $\mathrm{VL}(1)$ & $\mathrm{St}_{\mathrm{i}} \leq \mathrm{P} 25$ & $\mathrm{St}_{\mathrm{i}} \leq 0.5$ \\
& $\mathrm{~L} \mathrm{(2)}$ & $\mathrm{P} 25<\mathrm{St}_{\mathrm{i}} \leq \mathrm{P} 50$ & $0.5<\mathrm{St}_{\mathrm{i}} \leq 0.8$ \\
& $\mathrm{M}(3)$ & $\mathrm{P} 50<\mathrm{St}_{\mathrm{i}} \leq \mathrm{P} 75$ & $0.8<\mathrm{St}_{\mathrm{i}} \leq 1.2$ \\
Response & $\mathrm{H}(4)$ & $\mathrm{St}_{\mathrm{i}}>\mathrm{P} 75$ & $\mathrm{St}_{\mathrm{i}}>1.2$ \\
& Optimal (0) & $\mathrm{Rs}_{\mathrm{i}} \geq \mathrm{P} 50$ & $\mathrm{Rs}_{\mathrm{i}} \geq 0.75$ \\
& Insufficient (4) & $\mathrm{Rs}_{\mathrm{i}}<\mathrm{P} 50$ & $\mathrm{Rs}_{\mathrm{i}}<0.75$
\end{tabular}

VL: Very low; L: low; M: moderate; H: high; P25: 25th Percentile; P50: 50th Percentile; P75: 75th Percentile. *from Gómez et al. (2019).
The metadata of each variable used to estimate Pressure, State and Response factors for each marina is collated and processed by generating a database from the information gathered from the questionnaires and using Google Earth and ArcGIS (ESRI) (Table 2).

\section{Results}

\subsection{Classification of marinas}

Data were compiled by WHP partners for 105 marinas located in the United States, Dutch and French Caribbean, Portugal, Spain, Ireland, United Kingdom, France, Germany, Greece, South Africa, Israel, United Arab Emirates, China, Singapore, Italy, Australia, and New Zealand. Of the marinas included in this study, most were in Europe (41.9\%), followed by Australasia (27.6\%), North America and the Caribbean (21.9\%), Asia (7.6\%), with only 1\% in Africa (Fig. 2). Marinas were reported in all water categories in Europe and America and all four structural types of marinas were found in estuarine waters in America, Europe and Australasia, and in the coastal waters of America and Asia (Fig. 2).

Related the typologies of the 105 marinas assessed (Fig. 3a), anchorage was the most common type of marina (32\%), followed by a relatively similar representation of harbour (26\%), dock $(21 \%)$ and interior marinas (21\%). From these 105 marinas, there were three geographic zones in which information was collected in a greater number of them: Cantabrian Sea (8 marinas), Chesapeake Bay (12 marinas) and Sydney Harbour (19 marinas); allowing a more specific study on these zones. As an example, the harbour type, the interior type and the anchorage type were majority at Cantabrian Sea (Fig. 3b), Chesapeake Bay (Fig. 3c), and Sydney Harbour (Fig. 3d), respectively.

In the majority of locations marinas were located in estuarine waters $(69 \%)$, followed by $29 \%$ situated in coastal waters and only $2 \%$ of marinas located in freshwater. However, in Chesapeake Bay (Fig. 3c) and Sydney Harbour (Fig. 3d), marinas were all located in estuaries, while in the Cantabrian Sea (Fig. 3b) marinas were in coastal and estuarine waters.

\subsection{Global-scale marina enviromental risk assessment}

In general, $41 \%$ (43) of the marinas were considered as low risk, whereas $32 \%$ (34) showed moderate risk for water quality, respectively (Fig. 4a). There were negligible marinas with very low-risk (2\%). The percentage of high-risk and very-high-risk marinas was $15 \%$ and $10 \%$, respectively. There were regions where four-of-five risk categories were represented (e.g. the Cantabrian Sea, Fig. 4b), and areas where low and moderate-risk marinas made up the majority, as in Chesapeake Bay (92\%) (Fig. 4c) and Sydney Harbour (95\%) (Fig. 4d). A graphical representation of the Global Atlas of the environmental risk of marinas on water quality, considering water quality as a global concept of quality of aquatic systems, developed here is appended as an interactive supplementary data file for use on the Google Earth platform.

\subsubsection{Pressure}

$90 \%$ of marinas were reported as having low boat densities $(<0.5$ normalized intensity of navigation). Marinas with the highest densities ( $\approx 0.7$ normalized intensity of navigation) were anchorage types located in Australasia. Globally, $59 \%$ of marinas had fuel stations, while $38 \%$ had dry docks and $30 \%$ had both services (fuel stations and dry docks). Most marinas in Australasia had a very low need of dredging interventions, as they were mainly anchorage types (i.e. deep natural basins). On other continents, except Europe, roughly 50\% of marinas had a very high need for dredging activities. In European marinas, the need for dredging was highly variable, depending on marina structural types and substrate. The studied marinas were mainly located in artificial areas as industrial, mining and urban (73\%), some in natural areas as forests (20\%), and a few were close to agricultural areas (7\%). 


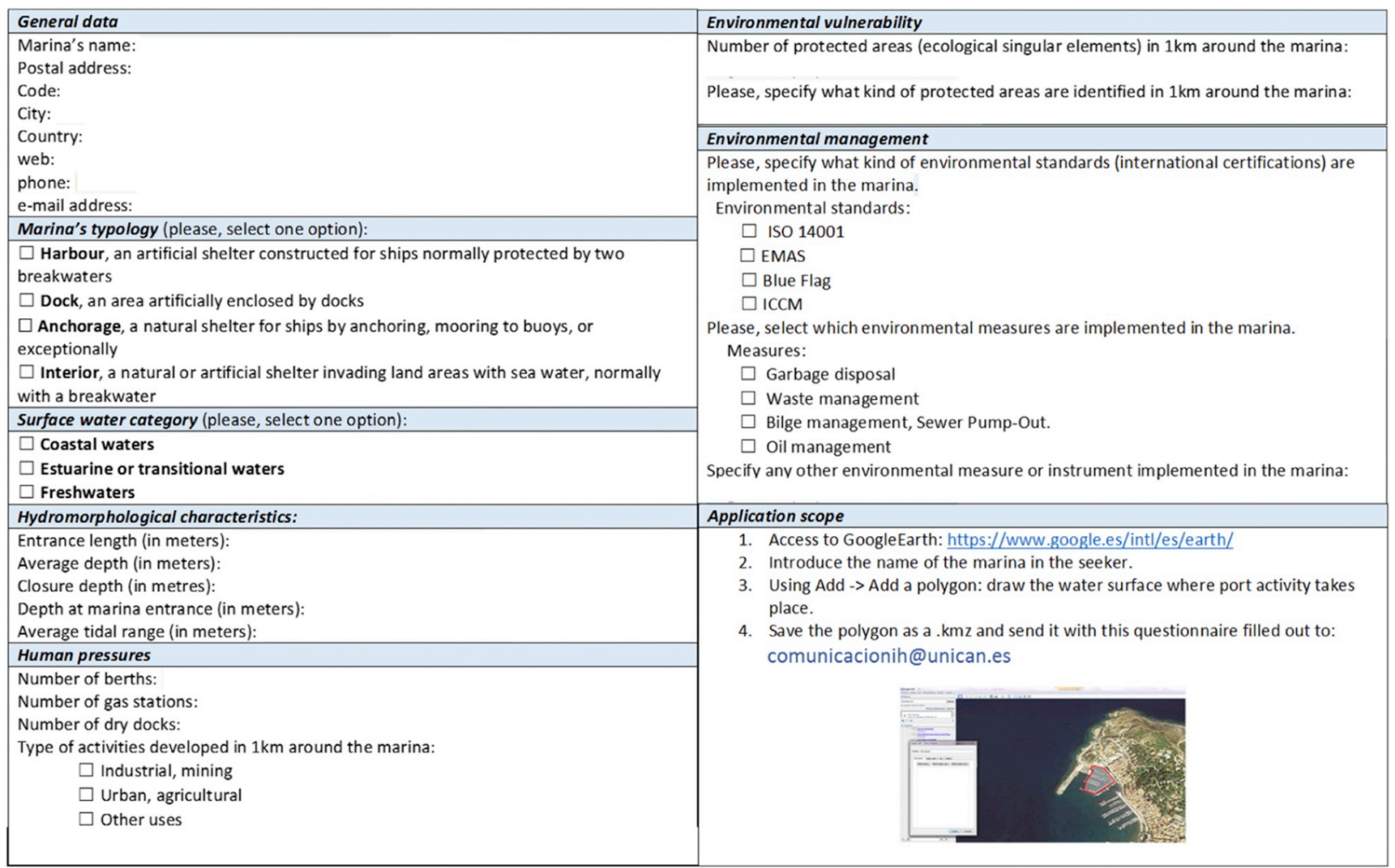

Fig. 1. Example of questionnaire to characterise each marina.

Table 2

Factors, variables, data sources, methods and tools to collect all the needed information.

\begin{tabular}{|c|c|c|c|}
\hline Factor & Variable & Data source & Method/Tool \\
\hline \multirow[t]{8}{*}{ Pressure } & Water polygon where the marina activity takes place & Own & Draw polygons \\
\hline & Water surface area $\left(\mathrm{m}^{2}\right)$ & Own & Calculate geometry \\
\hline & Number of berths & Managers and marina's official web site & - \\
\hline & Number of fuel stations & Managers and marina's official web site & - \\
\hline & Number of dry docks & Managers and marina's official web site & - \\
\hline & Marina's structural type & Own & - \\
\hline & Type of substrate & dbSEabed (Reid et al., 2006), EMODnet (Populus et al., 2017) & Select by location \\
\hline & Land uses & Globe Land 30 (Hen et al., 2015) & Select by location \\
\hline \multirow[t]{6}{*}{ State } & Water surface area $\left(\mathrm{m}^{2}\right)$ & Own & Calculate geometry \\
\hline & Diameter of the smallest circle enclosing the water polygon (m) & Own & Minimum bounding geometry \\
\hline & Minimum length of the entrance (m) & Own & Ruler \\
\hline & Medium tidal range $(\mathrm{m})$ & GOS dataset (Cid et al., 2014) & Select by location \\
\hline & Number of protected areas & $\begin{array}{l}\text { World Database on Protected Areas (UNEP-WCMC \& IUCN, } \\
\text { 2017) }\end{array}$ & Select by location \\
\hline & Marina's structural type & Own & - \\
\hline \multirow[t]{2}{*}{ Response } & Adopted environmental measures & Managers and marina's official web site & - \\
\hline & Adopted international environmental instruments & Managers and marina's official web site & - \\
\hline
\end{tabular}

\subsubsection{State}

Complexity Tidal Range Index (CTRI, Gómez et al., 2017) values ranged from 2928.8 (a marina in Germany, interior type with a very low tidal range) to 0.8 (a marina in Australia, interior type with a high tidal range). In terms of adjacent protected areas, the analysed marinas had none (41\%), 1 or $2(35 \%)$ or from 3 to $6(24 \%)$ protected areas in their surroundings; a single anchorage in Spain had seven protected areas in its surroundings. Most marinas were considered moderately natural, except for the marinas located in Australasia, which were considered highly natural.

\subsubsection{Response}

General response management measures, including garbage collection (82\%), waste management (72\%), bilge management (65\%) and oil management $(59 \%)$ were relatively widely adopted across the study marinas. Only $9 \%$ of marinas applied no measures, while $44 \%$ of the marinas applied all four measures. In total, $76 \%$ of marinas confirmed that no environmental instruments were applied to improve their environmental profile. Just $19 \%$ of marinas applied an international standard instrument, and only 5\% implemented more than one international standard instrument.

Classifying results by marina structural type (anchorage, dock, 


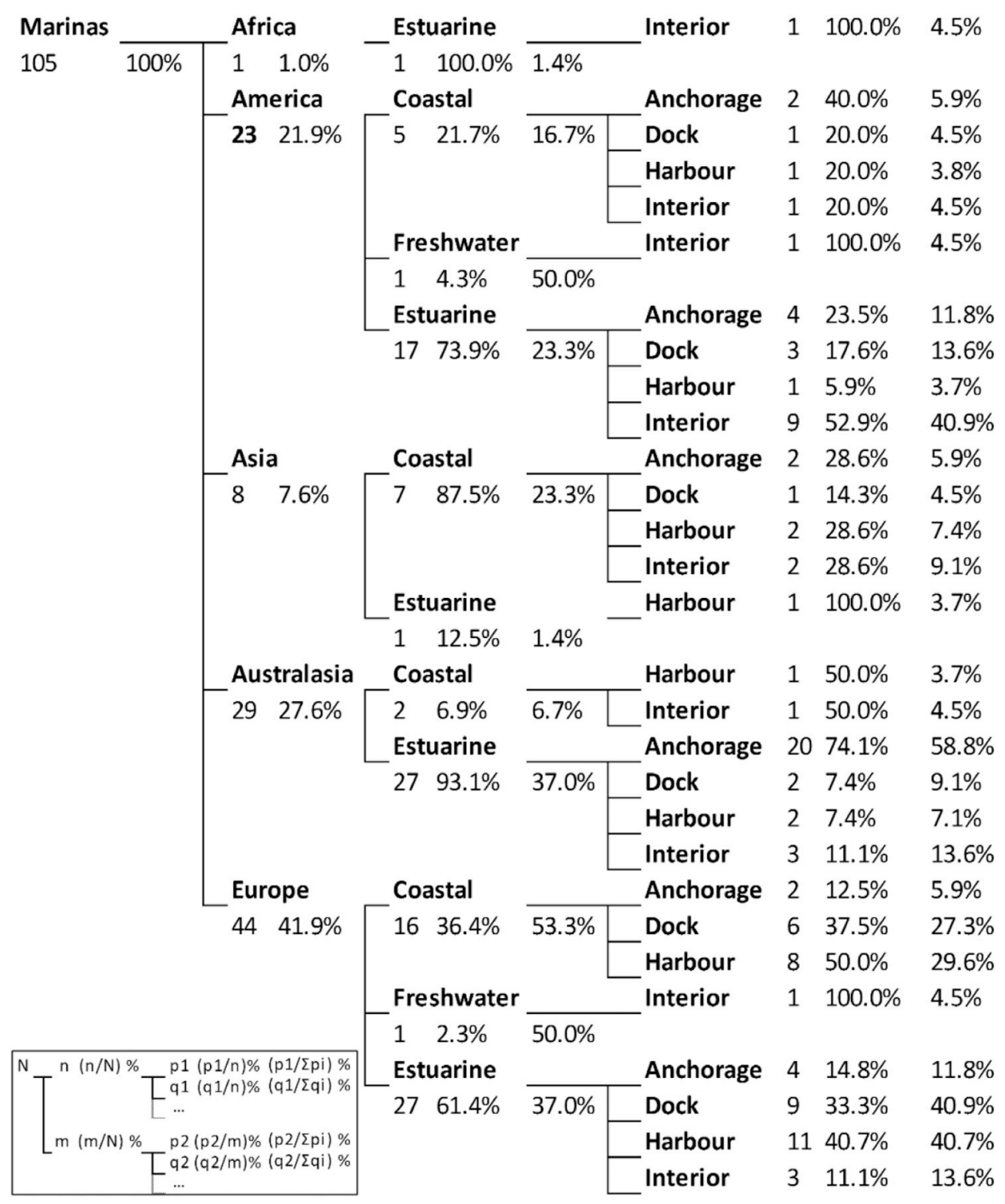

Fig. 2. The general tree of the study areas and their relative percentages of occurrence in each continent, grouped by water category and marina type classification.

harbour and interior), the proportion of assessment categories of Pressure (Fig. 5a), State (Fig. 5b), Response (Fig. 5c) and Risk (Fig. 5d) are represented. Anchorage marinas were typically of very low or low Pressure, were of a moderate to high State and, generally, displayed an optimal Response, largely resulting in low or moderate risk to water quality. Dock type marinas were more variable with respect to the inherent pressures they faced regarding water quality; a greater number of these marinas were identified as being in the low (6 marinas) and moderate (10 marinas) categories, with some dock marinas being categorised as having very low (2 marinas) and high (4 marinas) Pressure. Dock type marinas were typically of very low State, despite optimal Response mechanisms being in place. The integration of risk factors suggests that dock type marinas exhibit very low ( 2 marinas), to high ( 2 marinas) environmental risk, tending toward low (13 marinas) to moderate risk (5 marinas). Harbour marinas were typically characterised by high Pressure on water quality and were of highly variable State (categories ranging from very low to high). However, almost 50\% of these marinas had optimal management strategies in place. The combination of risk factors led to a similar distribution of harbour types among the different categories of risk. Finally, interior marinas were very mixed in terms of the level of Pressure and environmental conditions (State), many of which (30\%) implemented sub-optimal management Responses. Consequently, environmental risk in these interior marinas was very mixed.

\section{Discussion}

4.1. Challenges of applying MERA at a global scale

Our findings indicate that the MERA methodological procedure is adequate to be applied at both national (Gómez et al., 2019) and global scales, and the conceptual model was confirmed as being suitable for a range of different countries worldwide. The driving forces defined, the human activities selected, the environmental conditions considered, and the evaluation of environmental management were all found to be applicable at a global scale. The factors (Pressures, State and Response) and parameters selected to estimate Pressures (Navigation Activity, Port Activity, Dredging Activity, External Activity), State (Susceptibility, Ecological Value, Naturalness) and Response (Measures and Instruments Adopted) at a national scale (Gómez et al., 2019) did not need to be modified or adapted to be implemented at the global scale.

The main challenge in applying this method to other countries was the availability of suitable data. The questionnaire used here was designed to enable information to be gathered from different stakeholders 


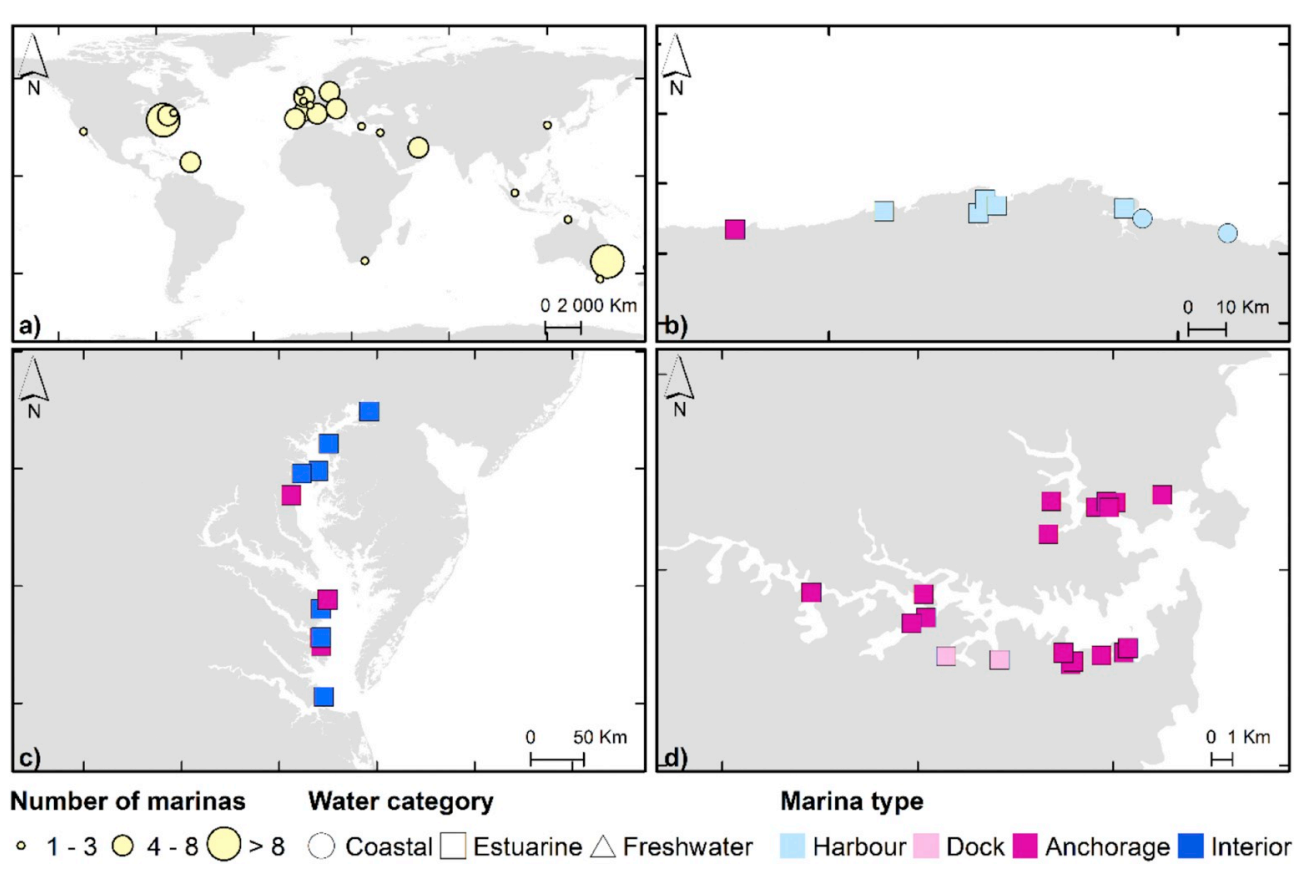

Fig. 3. a) Worldwide location of the 105 marinas under study where the size of the circles is relative to the number of marinas identified in each zone. Location, specific water categories (shapes) and marina types (colours) at: b) Cantabrian Sea, Spain, Europe; c) Chesapeake Bay, Virginia, United States of America; d) Sydney Harbour, Australia, Australasia. (For interpretation of the references to colour in this figure legend, the reader is referred to the Web version of this article.) and institutions in a homogenous and standardized way. Global data sources identified (dbSEabed, Reid et al., 2006; EMODnet, Populus et al., 2017; Globe Land 30, Hen et al., 2015, GOS dataset, Cid et al., 2014; World Database on Protected Areas, UNEP-WCMC \& IUCN, 2017) that were used could be appropriate in the future to increase the number of case studies, since these resources are widely accessible and easy to use.

The integration of parameters, as well as the use of percentiles for the assessment criteria, seems to be convenient to assess the environmental risk to water quality at marinas worldwide. However, new thresholds can be recalculated for a new context following the adaptive management process. The consideration of equidistant percentiles allows obtaining specific thresholds for a specific region/country/bay or a specific marina typology (i.e., harbours) (Gómez et al., 2017). For example, the environmental risk assessment associated with the eight marinas located in the Cantabrian region (Spain) differed depending on the scale considered (Fig. 6). This is because thresholds are relative to the areas under study. But, whatever the study area, this MERA approach will allow a prioritization of management measures to be applied in those marinas obtaining higher risk values. At global scale (Fig. 6a), Cantabrian marinas show a higher priority than at the national scale (Fig. 6b). Using percentiles as thresholds allows the environmental management to be based on the continuous improvement approach, since thresholds would change under a new situation (Gómez et al., 2019). The method is therefore flexible, dynamic and can be adapted to a specific area of interest through an objective and costeffective classification (Knights et al., 2014).

Notwithstanding the above, some improvements could be undertaken to estimate the navigation and dredging activities. The intensity of navigation is a difficult parameter to accurately quantify with a

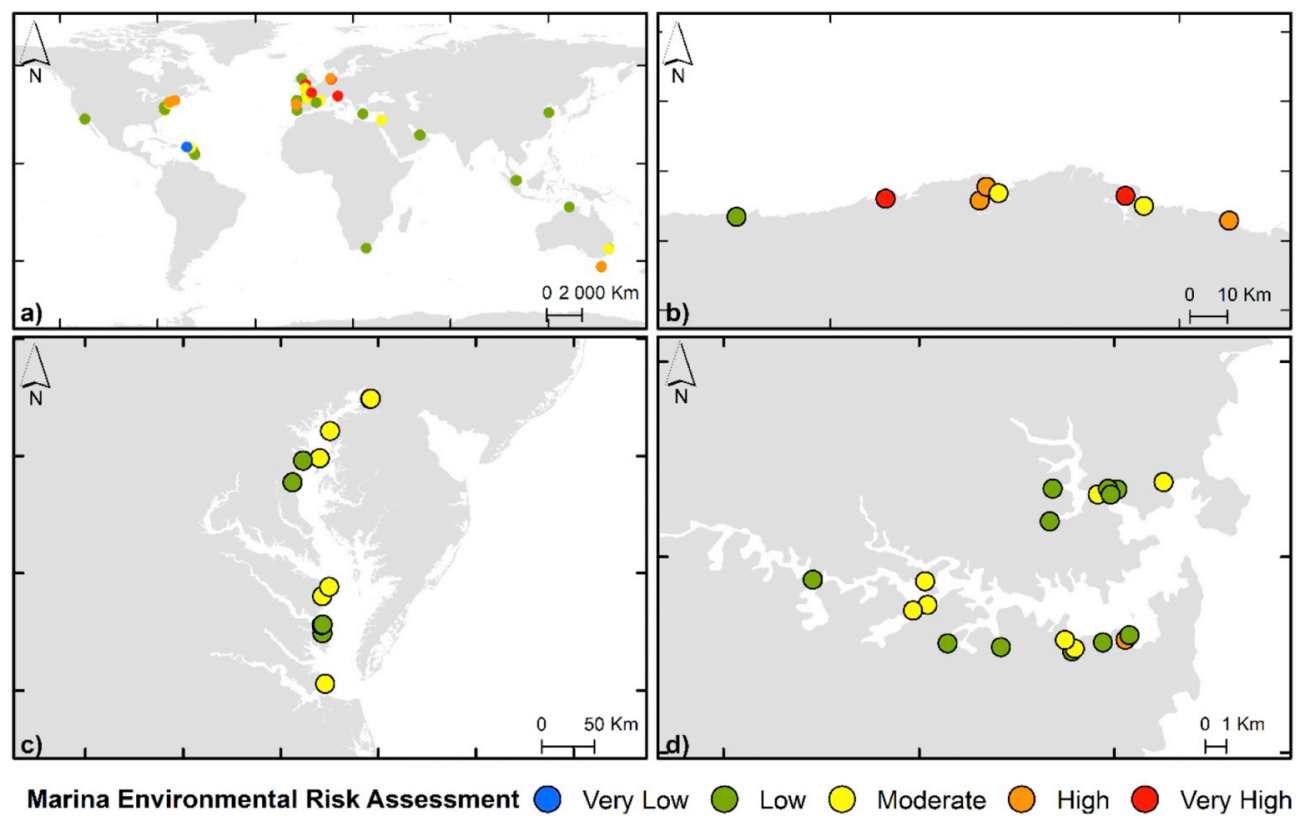

Fig. 4. Marina Environmental Risk Assessment results at: a) global scale; b) Cantabrian Sea; c) Chesapeake Bay; d) Sydney Harbour. 
a)

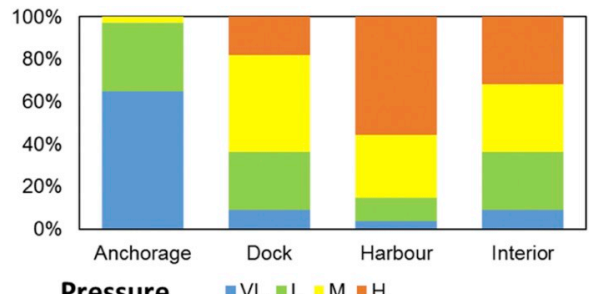

c)

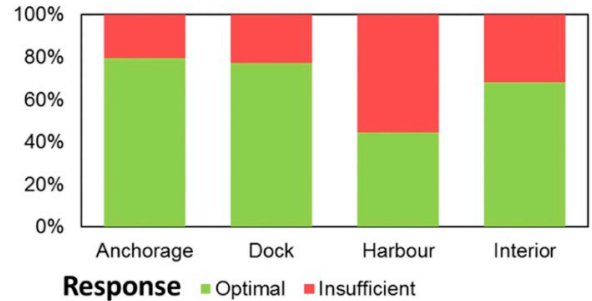

b)

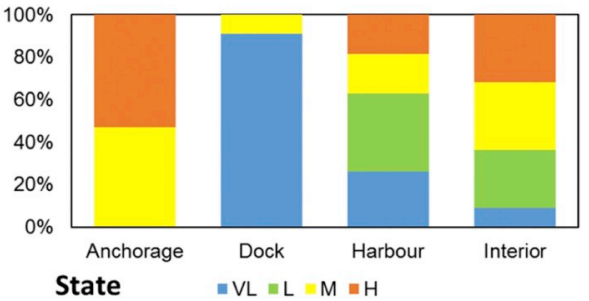

d)

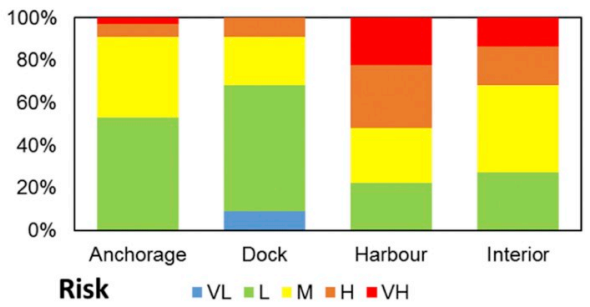

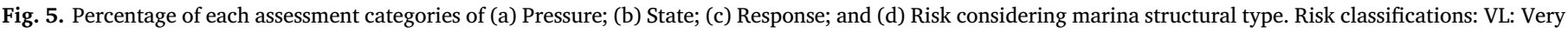
low; L: low; M: moderate; H: high; VH: very high.

metric because of the lack of clear and accessible records on boat movement. The simplest approach is to use a ratio of the number of berths per unit area, but it is relatively insensitive to the size of the marina water domain. On the other hand, dredging frequency could not be estimated by the closure depth (Hallermeier, 1981) like in the Spanish national-level study (Gómez et al., 2019) due to the lack of data. Thus, the estimation of dredging activity through the type of substrate was an oversimplification. Dredging activity estimation could be based on the real dredged volumes, considering, for example the annual dredged volume.

Besides, further research should be conducted to develop indicators to account for impacts specifically related to the recreational navigation sector, such as the abundance of invasive species (Airoldi et al., 2015; Ferrario et al., 2017; Lenders et al., 2001). Finally, it is important to note that the MERA process provides an estimation of the potential impact of boating activities on water systems. However, the real environmental conditions should be quantified through a regular monitoring of the environmental quality. Traditionally, the evaluation of the quality of water systems has been conducted by sampling and laboratory analysis and abiotic and biotic indices (Ponti et al., 2009; Ondiviela et al., 2013). Nowadays, data of environmental quality from monitoring programs, satellite images or forecast models could be used to calibrate the MERA process.

\subsection{Potential applications of a MERA global observatory}

Spatial data infrastructures (SDI) emerged in the last few decades as an approach to improve decision-making and resource management in terms of sustainable development (Strain et al., 2006). Spatial data are essential for this purpose since many of the critical problems that arise in dealing with pollution of aquatic systems are inherently spatial issues
(Valdor et al., 2016). For that reason, intergovernmental institutions coordinate cooperation programs to exchange marine data and information through these data infrastructures (e.g., The Intergovernmental Oceanographic Commission of UNESCO (IOC-UNESCO) that supports the programme "International Oceanographic Data and Information Exchange" (IODE)). Global implementation of MERA will provide relevant information to define global approaches to sustainability, through an observatory of marinas on water quality. MERA, as a valuable management tool to support decision-making processes, could be embedded in marine SDIs, marine Spatial data infrastructures, such as in the UN Atlas of the Oceans, developed under the authority of UNOceans, or in the IH-MSP, a platform which supports the Marine Spatial Planning (msp.ihcantabria.com).

\section{Conclusions}

The study generates an atlas of environmental risk of marinas on water quality worldwide. Applying this MERA approach to 105 marinas spread across the globe has confirmed the usefulness, versatility and adaptability of this procedure as both a first tool to compare the environmental risks within and among regions (i.e. for area based management), to identify world's best practice (i.e. to optimize existing management) and as a tool to understand and adjust for risks in future development (i.e. improved planning). This study has confirmed the adequacy of the conceptual model, the indicators and the assessment system to reliably estimate the environmental risk of marinas at a global scale. The developed MERA approach provides an assessment of marina water quality conditions and can facilitate development of optimal management strategies for individual marinas or marinas grouped at regional, national or international scale. Further research should aim to implement the presented methodology in a larger number of marinas

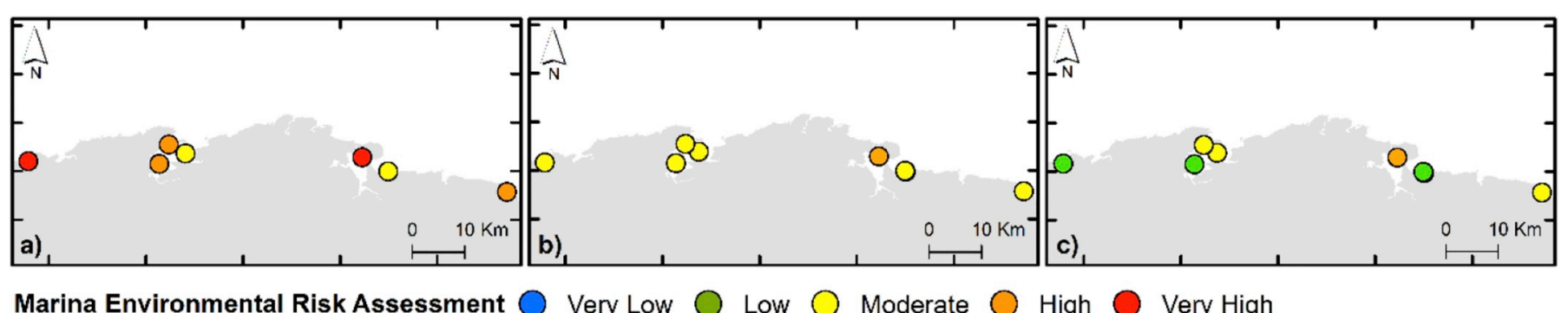

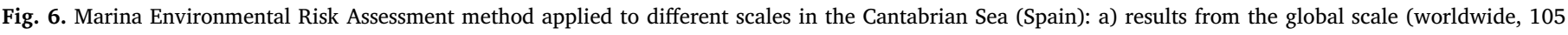
marinas); b) results at national level (Spain, 320 marinas, Gómez et al., 2019); c) results at local level (Cantabrian region, 8 marinas). 
all over the world, allowing for an optimized environmental risk observatory of water quality for the recreational harbour sector.

\section{Acknowledgments}

This work was supported by the World Harbour Project (www. worldharbourproject.org) and by the European Regional Development Fund (ERDF) through the 2014-2020 operational program of Cantabria (EYEPORT project, 2016/INN/039, INNOVA 2016). Authors would like to thank all the marina managers worldwide who provided their time to complete the forms to gather relevant information for this study. Thanks, is also extended to Dain Mc Parland who facilitated data collection among marine managers in the UAE and to Sheila Abad for her technical support on ArcGIS and Google Earth.

\section{Appendix A. Supplementary data}

Supplementary data associated with this article can be found, in the online version, at https://doi.org/10.1016/j.marpolbul.2019.110661.

\section{References}

UNEP-WCMC \& IUCN, 2017. Protected Planet: the World Database on Protected Areas (WDPA)/The Global Database on Protected Areas Management Effectiveness (GDPAME)] [On-Line], [01/12/2017], Cambridge, UK: UNEP-WCMC and IUCN. Available at: www.protectedplanet.net.

Airoldi, L., Turon, X., Perkol-Finkel, S., Rius, M., 2015. Corridors for aliens but not for natives: effects of marine urban sprawl at a regional scale. Divers. Distrib. 21 755-768. https://doi.org/10.1111/ddi.12301.

Bishop, J.D.D., Wood, C.A., Yunnie, A.L.E., Griffiths, C.A., 2015. Unheralded arrivals: non-native sessile invertebrates in marinas on the English coast. Aquat. Invasions 10, 249-264. https://doi.org/10.3391/ai.2015.10.3.01.

Brida, J.G., Zapata, S., 2009. Cruise tourism: economic, socio-cultural and environmental impacts. Int. J. Leis. Tour. Mark. 1 (3), 205-226. https://doi.org/10.1504/IJLTM. 2010.029585.

Carić, H., Oran Klobu Car, G., Stambuk, A., 2016. Ecotoxicological risk assessment of antifouling emissions in a cruise ship port. J. Clean. Prod. 121, 159-168. https://doi. org $/ 10.1016 /$ j.jclepro.2014.08.072.

Cid, A., Castanedo, S., Abascal, A.J., Menéndez, M., Medina, R., 2014. A high resolution hindcast of the meteorological sea level component for Southern Europe: the GOS dataset. Clim. Dyn. 43 (7-8), 2167-2184. https://doi.org/10.1007/s00382-0132041-0.

Dafforn, K.A., Glasby, T.M., Johnston, E.L., 2009. Links between estuarine condition and spatial distributions of marine invaders. Divers. Distrib. 15 (5), 807-821. https://doi. org $/ 10.1111 / \mathrm{j} .1472-4642.2009 .00587 . x$.

Davenport, J., Davenport, J.L., 2006. The impact of tourism and personal leisure transport on coastal environments: a review. Estuarine. Coastal and Shelf Science 67, 280-292. https://doi.org/10.1016/j.ecss.2005.11.026.

Di Franco, A., Graziano, M., Franzitta, G., Felline, S., Chemello, R., Milazzo, M., 2011. Do small marinas drive habitat specific impacts? A case study from Mediterranean Sea. Mar. Pollut. Bull. 62, 926-933. https://doi.org/10.1016/j.marpolbul.2011.02.053.

ECORYS, 2015. Study on the Competitiveness of the Recreational Boating Sector. Final report, pp. 146.

EPA, 1985. Coastal Marina Assessment Handbook. Environmental Protection Agency, Atlanta, pp. 210.

EPA, 2003. Shipshape Shores and Waters. A Handbook for Marina Operators and Recreational boaters.EPA-841-B-03-001. U.S. Environmental Protection Agency, Washington, DC, pp. 22

European Commission, 2009. Regulation (EC) No 1221/2009 of the European Parliament and the Council, of 25 November 2009, on the Voluntary Participation by Organisations in a Community Eco-Management and Audit Scheme (EMAS), Repealing Regulation (EC) No 761/2001 and Commission Decisions 2001/681/EC and 2006/193/EC.

FEE, 2007. The Blue Flag, Eco-Label for Beaches and Marinas. pp. 12 Copenhagen.

Ferrario, J., Caronni, S., Occhipinti-Ambrogi, A., Marchini, A., 2017. Role of commercial harbours and recreational marinas in the spread of non-indigenous fouling species. Biofouling 1-10.

Firth, L.B., Browne, K.A., Knights, A.M., Hawkins, S.J., Nash, R., 2016. Eco-engineered rock pools: a concrete solution to biodiversity loss and urban sprawl in the marine environment. Environ. Res. Lett. 11, 94015. https://doi.org/10.1088/1748-9326/ 11/9/094015.

Gómez, A.G., Ondiviela, B., Fernández, M., Juanes, J.A., 2017. Atlas of susceptibility to pollution in marinas. Application to the Spanish coast. Mar. Pollut. Bull. 114 239-346. https://doi.org/10.1016/j.marpolbul.2016.09.009.

Gómez, A.G., Valdor, P.F., Ondiviela, B., Díaz, J.L., Juanes, J.A., 2019. Mapping the environmental risk assessment of marinas on water quality: the Atlas of the Spanish coast. Mar. Pollut. Bull. 139, 355-365. https://doi.org/10.1016/j.marpolbul.2019. 01.008.

Goodsir, F., Bloomfield, H.J., Judd, A.D., Kral, F., Robinson, L.A., Knights, A.M., 2015. A spatially resolved pressure-based approach to evaluate combined effects of human activities and management in marine ecosystems. ICES (Int. Counc. Explor. Sea) J. Mar. Sci. 72 (8), 2245-2256. https://doi.org/10.1093/icesjms/fsv080.

Hallermeier, R.J., 1981. A profile zonation for seasonal sand beaches from wave climate. Coast Eng. 4, 253-277. https://doi.org/10.1016/0378-3839(80)90022-8.

Haslett, S.K., 2009. Coastal Systems, second ed. Routledge, New York, 9780203893203pp. 240.

Hen, J., Chen, J., Liao, A., Cao, X., Chen, L., Chen, X., He, C., Han, G., Peng, S., Lu, M., Zhang, W., Tong, X., Mills, J., 2015. Global land cover mapping at 30m resolution: a POK-based operational approach. ISPRS J. Photogrammetry Remote Sens. 103, 7-27. https://doi.org/10.1016/j.isprsjprs.2014.09.002.

ISO, 2015. ISO 14001:2015, Environmental Management Systems - Requirements with Guidance for Use. pp. 35pp.

Kates, R.W., Parris, T.M., Leiserowitz, A.A., 2005. Editorial-What is sustainable development? Goals, indicators, values, and practice. Environment 47 (3), 8-21. https:// doi.org/10.1080/00139157.2005.10524444.

Knights, A.M., Koss, R.S., Robinson, L.A., 2013. Identifying common pressure pathways from a complex network of human activities to support ecosystem-based management. Ecol. Appl. 23, 755-765. https://doi.org/10.1890/12-1137.1.

Knights, A.M., Culhane, F., Hussain, S.S., Papadopoulou, K.N., Piet, G.J., Raakær, J., Rogers, S.I., Robinson, L.A., 2014. A step-wise process of decision-making under uncertainty when implementing environmental policy. Environ. Sci. Policy 39, 56-64. https://doi.org/10.1016/j.envsci.2014.02.010.

Knights, A.M., Firth, L.B., Thompson, R.C., Yunnie, A.L.E., Hiscock, K., Hawkins, S.J., 2016. Plymouth - a world harbour through the ages. Regional Studies in Marine Science 8, 297-307. https://doi.org/10.1016/j.rsma.2016.02.002.

Kovačić, M.,M., Favro, S., Mezak, V., 2016. Construction of nautical tourism ports as an incentive to local development. Environ. Eng. Manage. J. 15 - 2, 395-403.

Kuznetsov, A., Dinwoodie, J., Gibbs, D., Sansom, M., Knowles, H., 2015. Towards a sustainability management system for smaller ports. Mar. Policy 54, 59-68. https:// doi.org/10.1016/j.marpol.2014.12.016.

Lenders, H.H.R., Leuven, R.S.E.W., Nienhuis, P.H., de Nooij, R.J.W., Van Rooij, S.A.M., 2001. Bio safe: a method for evaluation of biodiversity values on the basis of political and legal criteria. Landsc. Urban Plan. 55, 121-137. https://doi.org/10.1016/S01692046(01)00149-9.

Mali, M., Dell'Anna, M.M., Mastrorilli, P., Damiani, L., Piccinni, A.F., 2017. Assessment and source identification of pollution risk for touristic ports: heavy metals and polycyclic aromatic hydrocarbons in sediments of 4 marinas of the Apulia region (Italy). Mar. Pollut. Bull. 114 (2), 768-777. https://doi.org/10.1016/j.marpolbul. 2016.10.063.

Manigel, U., 2011. IMCI Blue Star Marina Certification - a transparent system to indicate the quality level of marinas. J. Coast. Res. 61, 123-125. https://doi.org/10.2112/ S161-001.

McGranahan, G., Balk, D., Anderson, B., 2007. The rising tide: assessing the risks of climate change and human settlements in low elevation coastal zones. Environ. Urbanization 19, 17-37. https://doi.org/10.1177/0956247807076960.

Mihalic, T., 2016. Sustainable-responsible tourism discourse - towards "responsustable" tourism. J. Clean. Prod. 111, 461-470. https://doi.org/10.1016/j.jclepro.2014.12. 062.

Moreau, R., 2009. Nautical Activities: what Impact on the Environment? A Life Cycle Approach for "Clear Blue" Boating - Commissioned by the European Confederation of Nautical Industries - Ecni, second ed. vol. 2009. pp. 66.

Neira, C., Cossaboon, J., Mendoza, G., Hoh, E., Levin, L.A., 2017. Occurrence and distribution of polycyclic aromatic hydrocarbons in surface sediments of San Diego Bay marinas. Mar. Pollut. Bull. 114 (1), 466-479. https://doi.org/10.1016/j.marpolbul. 2016.10.009.

Neira, C., Mendoza, G., Hoh, E., Levin, L.A., 2018. Polychlorinated biphenyls (PCBs) in recreational marina sediments of San Diego Bay, southern California. Mar. Pollut. Bull. 126, 204-214. https://doi.org/10.1016/j.marpolbul.2017.10.096.

OECD, 2003. Environmental Indicators. Development, Measurement and Use. The Organisation for Economic Co-operation and Development, Paris, pp. 37.

Ondiviela, B., Gómez, A.G., Puente, A., Juanes, J.A., 2013. A pragmatic approach to define the ecological potential of water bodies heavily modified by the presence of ports. Environ. Sci. Policy 33, 320-333. https://doi.org/10.1016/j.envsci.2013.07. 001.

Parra, N.M., Nagi, A., Kersten, W., 2018. Risk Assessment Methods in Seaports: A Literature Review, vol. 24. Publications of the Hazard Project, pp. 2018.

Pearson, S., Windupranata, W., Pranowo, S.W., Putri, A., Ma, Y., Vila-Concejo, A., Fernández, E., Méndez, G., Banks, J., Knights, A.M., Firth, L.B., Breen, B.B., Jarvis, R., Aguirre, J.D., Chen, S., Smith, A.N.H., Steinberg, P., Chatzinikolaou, E., Arvanitidis, C., 2016. Conflicts in some of the World harbours: what needs to happen next? Maritime Studies 15, 10. https://doi.org/10.1186/s40152-016-0049-x.

PIANC, 2006. Environmental Risk Assessment of Dredging and Disposal Operations. PIANC Secretariat General, Brussels.

Ponti, M., Vadrucci, M.R., Orfanidis, S., Pinna, M., 2009. Biotic indices for ecological status of transitional water ecosystems. Transitional Waters Bulletin 3, 32-90. https://doi.org/10.1285/i1825229Xv3n3p32.

Populus, J., Vasquez, M., Albrecht, J., Manca, E., Agnesi, S., AL Hamdani, Z., Andersen, J., Annunziatellis, A., Bekkby, T., Brusch, i A., Doncheva, V., Drakopoulou, V., Duncan, G., Inghilesi, R., Kyriakidou, C., Lalli, F., Lillis, H., Mo, G., Muresan, M., Salomidi, M., Sakellariuo, D., Simboura, M., Teaca, A., Tezcan, D., Todorova, V., Tunesi, L., 2017. EUSeaMap, A European Broad-Scale Seabed Habitat Map. Final Report. pp. 174.

Reid, J.A., Reid, J.M., Jenkins, C.J., Zimmermann, M., Williams, S.J., Field, M.E., 2006 usSEABED: Pacific Coast (California, Oregon, Washington) Offshore SurficialSediment Data Release: U.S. Geological Survey Data Series 182. version 1.0. pp.1-57. < Online at. https://pubs.usgs.gov/ds/2006/182/. 
Rivero, N.K., Dafforn, K.A., Coleman, M.A., Johnston, E.L., 2013. Environmental and ecological changes associated with a marina. Biofouling 29 (7), 803-815. https://doi. org/10.1080/08927014.2013.805751.

Ryu, J., Khim, J.S., Kang, S.G., Kang, D., Lee, C.H., Koh, C.H., 2011. The impact of heavy metal pollution gradients in sediments on benthic macrofauna at population and community levels. Environ. Pollut. 159 (10), 2622-2629. https://doi.org/10.1016/j. envpol.2011.05.034.

Seto, K.C., Fragkias, M., Guneralp, B., Reilly, M.K., 2011. A meta-analysis of global urban land expansion. PLoS One 6 (8), e23777. https://doi.org/10.1371/journal.pone. 0023777.

Smith, J., Shackley, S.E., 2006. Effects of the closure of a major sewage outfall on sublittoral, soft sediment benthic communities. Mar. Pollut. Bull. 52 (6), 645-658. https://doi.org/10.1016/j.marpolbul.2005.10.016.

Steinberg, P.D., Airoldi, L., Banks, J., Leung, K.M.Y., 2016. Introduction to the special issue on the world harbour project. Regional Studies in Marine Science 8 (2), 217-219. https://doi.org/10.1016/j.rsma.2016.10.001.

Strain, L., Rajabifard, A., Williamson, I., 2006. Marine administration and spatial data infrastructure. Mar. Policy 30, 431-441. https://doi.org/10.1016/j.marpol.2005.03. 005.

Turner, A., 2010. Marine pollution from antifouling paint particle. Mar. Pollut. Bull. 60, 159-171. https://doi.org/10.1016/j.marpolbul.2009.12.004.

United Nations, 2015a. World Urbanization Prospect: the 2014 Revision, vol. 32 United Nations, Department of Economic and Social Affairs, Population Division, New
York978-92-1-151517-6.

United Nations, 2015b. Transforming Our World: the 2030 Agenda for Sustainable Development 70/1. A/RES/, pp. 41.

United Nations, 2018. World Urbanization Prospects: the 2018 Revision. Key facts, United Nations, pp. 2.

UNWTO, 2017. Tourism Highlights, 2017 Edition. World Tourism Organization, pp. 16.

Valdor, P.F., Gómez, A.G., Velarde, V., Puente, A., 2016. Can a GIS toolbox assess the environmental risk of oil spills? Implementation for oil facilities in harbors. J. Environ. Manag. 170, 105-115. https://doi.org/10.1016/j.jenvman.2016.01.012.

Warnken, J., Dunn, J.K., Teasdale, P.R., 2004. Investigation of recreational boats as a source of copper at anchorage sites using time-integrated diffusive gradients in thin film and sediment measurements. Mar. Pollut. Bull. 49, 833-843. https://doi.org/10. 1016/j.marpolbul.2004.06.012.

Whitfield, A.K., Becker, A., 2014. Impacts of recreational motorboats on fishes: a review. Mar. Pollut. Bull. 83 (1), 24-31. https://doi.org/10.1016/j.marpolbul.2014.03.055.

Widmer, W.M., Underwood, A.J., 2004. Factors affecting traffic and anchoring patterns of recreational boats in Sydney Harbour, Australia. Landsc. Urban Plan. 66, 173-183. https://doi.org/10.1016/S0169-2046(03)00099-9.

Yılmaz, A., Karacık, B., Henkelmann, B., Pfister, G., Schramm, K.W., Yakan, S.D., Barlas, B., Okay, O.S., 2014. Use of passive samplers in pollution monitoring: a numerical approach for marinas. Environ. Int. 73, 85-93. https://doi.org/10.1016/j.envint. 2014. 07.013. 